\title{
Sub-micrometer Novolac-Derived Carbon Beads for High Performance Supercapacitors and Redox Electrolyte Energy Storage
}

Benjamin Krüner, ${ }^{1,2}$ Juhan Lee, ${ }^{1,2}$ Nicolas Jäckel,, ${ }^{1,2}$ Aura Tolosa, ${ }^{1,2}$ and Volker Presser ${ }^{1,2, *}$

1 INM - Leibniz Institute for New Materials, 66123 Saarbrücken, Germany

2 Department of Materials Science and Engineering, Saarland University, 66123 Saarbrücken, Germany

* Corresponding author's eMail: volker.presser@leibniz-inm.de 
Table S1: Electrode properties. Note the reduced active mass per electrode as a result of the increased porosity at comparable electrode thickness.

\begin{tabular}{lcccc}
\hline & $\begin{array}{c}\text { Electrode density } \\
\left(\mathbf{m g} / \mathbf{c m}^{\mathbf{3}}\right)\end{array}$ & $\begin{array}{c}\text { Active mass } \\
(\mathbf{m g})\end{array}$ & $\begin{array}{c}\text { Electrode } \\
\text { diameter }(\mathbf{m m})\end{array}$ & $\begin{array}{c}\text { Electrode } \\
\text { thickness }(\mathbf{m m})\end{array}$ \\
\hline $\mathrm{PNC}_{0 \mathrm{~h}}$ & 611 & 15.2 & 12 & 0.22 \\
\hline $\mathrm{PNC}_{0.25 \mathrm{~h}}$ & 442 & 8.5 & 12 & 0.17 \\
\hline $\mathrm{PNC}_{0.5 \mathrm{~h}}$ & 385 & 8.7 & 12 & 0.20 \\
\hline $\mathrm{PNC}_{1 \mathrm{~h}}$ & 230 & 3.9 & 12 & 0.15 \\
\hline $\mathrm{PNC}_{1.5 \mathrm{~h}}$ & 169 & 2.3 & 12 & 0.12 \\
\hline $\mathrm{PNC}_{2 \mathrm{~h}}$ & 161 & 3.1 & 12 & 0.17 \\
\hline
\end{tabular}



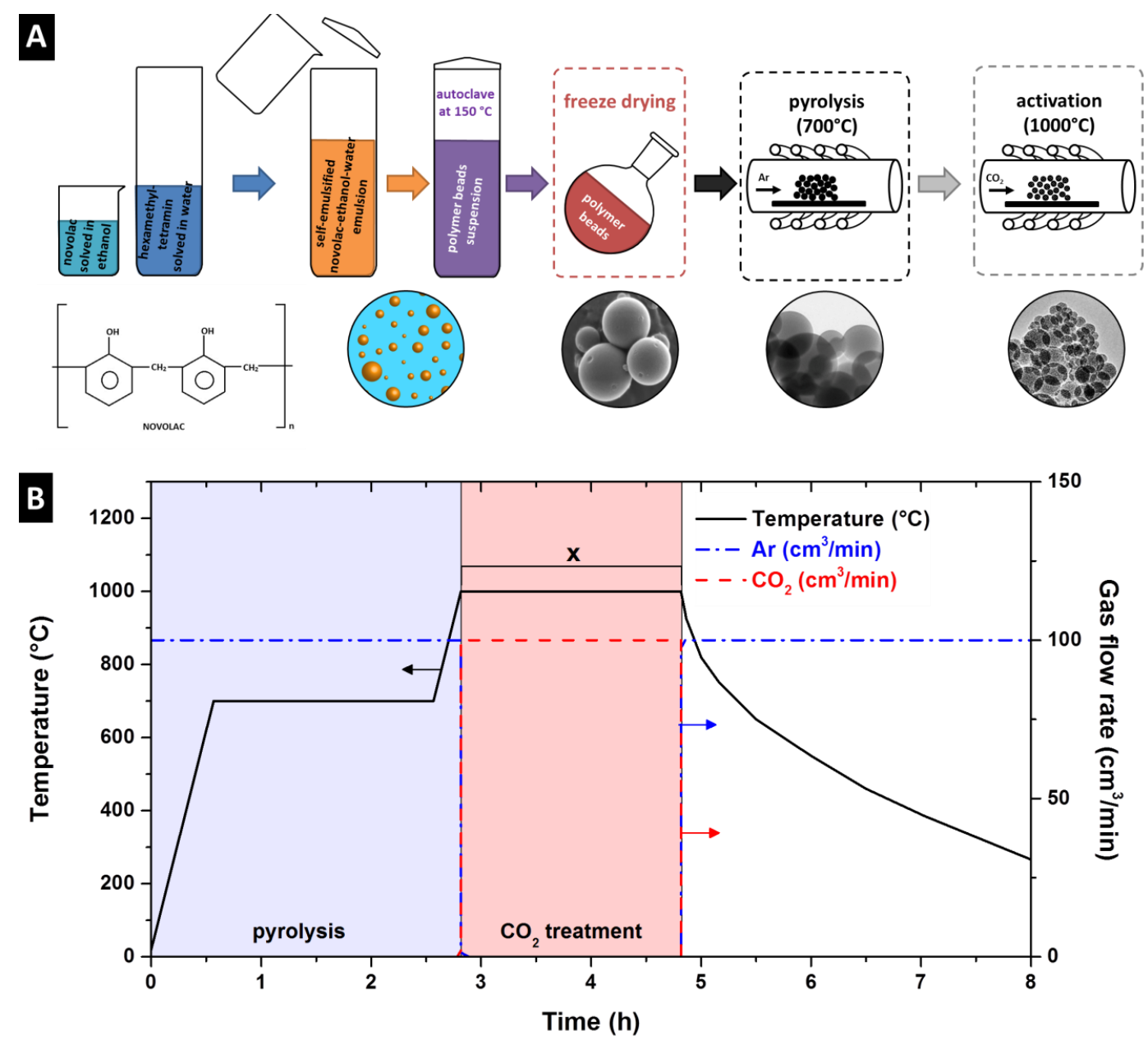

Figure S1: Schematic illustration of the synthesis route $(A)$ and processing conditions of the pyrolysis and $\mathrm{CO}_{2}$-treatment $(\mathrm{B})$. The parameter $\mathrm{X}$ denotes the duration of the $\mathrm{CO}_{2}$-treatment (physical activation), which was varied for the different experiments. 


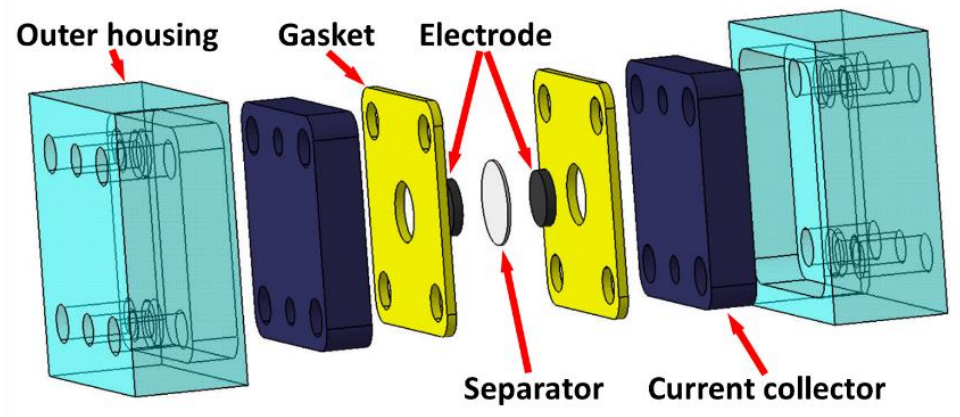

Figure S2: Schematic setup of the redox-electrolyte cell. 

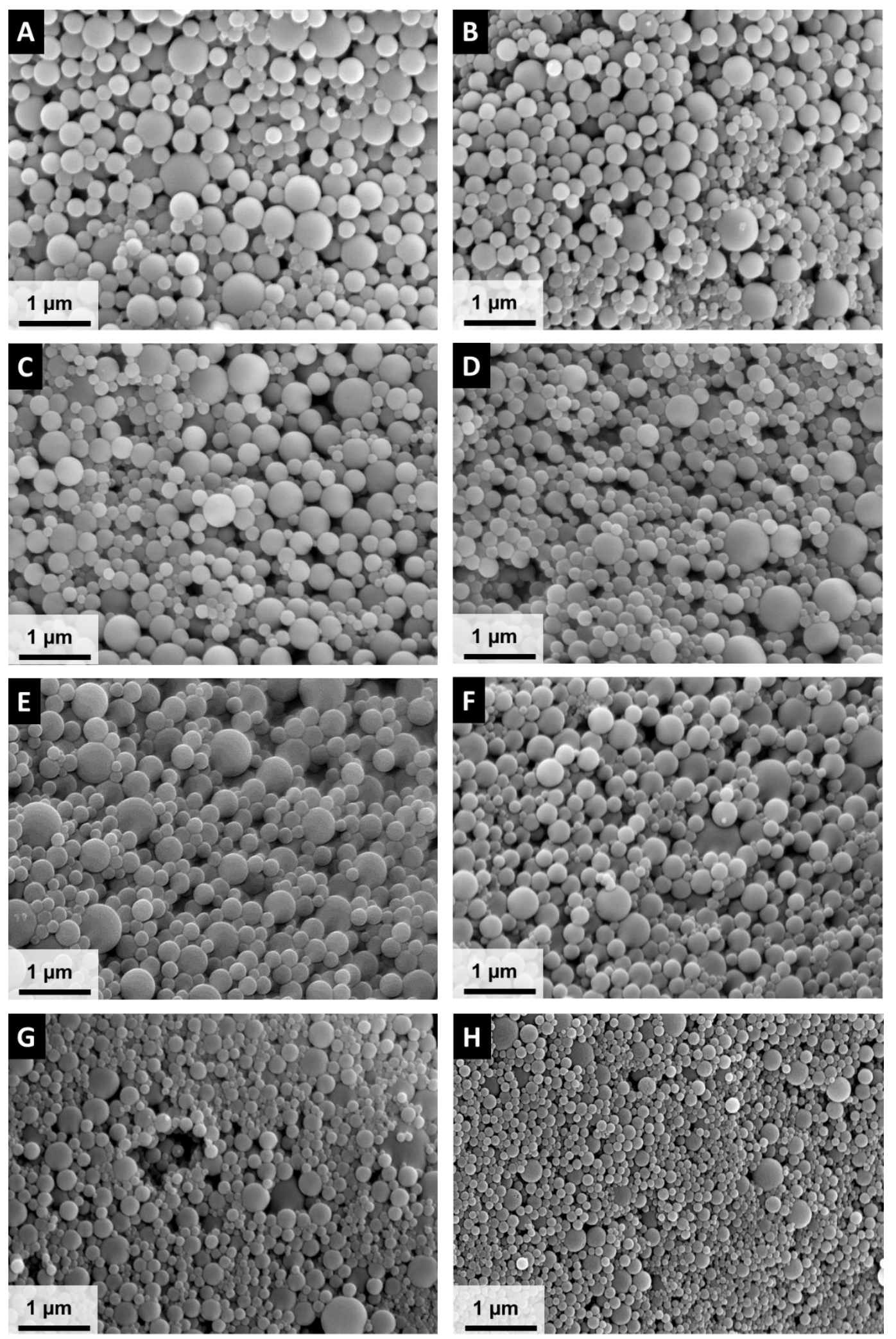

Figure S3: $\mathrm{SEM}$ images of $\mathrm{PNC}_{0 h}(\mathrm{~A}), \mathrm{PNC}_{0.25 h}(\mathrm{~B}), \mathrm{PNC}_{0.5 \mathrm{~h}}(\mathrm{C}), \mathrm{PNC}_{1 \mathrm{~h}}(\mathrm{D}), \mathrm{PNC}_{1.5 \mathrm{~h}}(\mathrm{E}), \mathrm{PNC}_{2 \mathrm{~h}}(\mathrm{~F}), \mathrm{PNC}_{2.5 \mathrm{~h}}$ $(\mathrm{G})$, and $\mathrm{PNC}_{3 \mathrm{~h}}(\mathrm{H})$. 

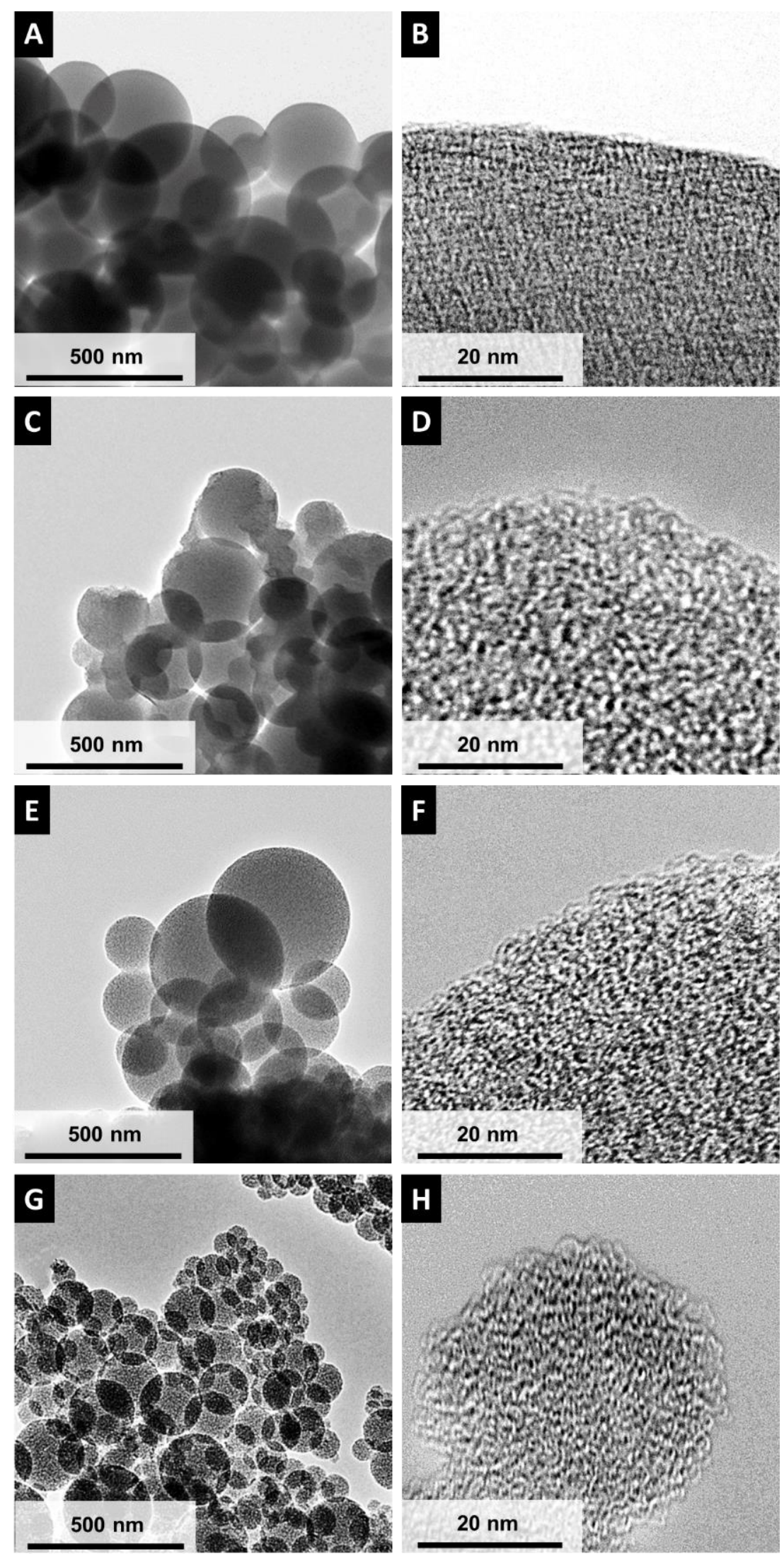

Figure S4: TEM images of the pyrolyzed $\mathrm{PNC}_{0 h}(\mathrm{a}, \mathrm{b})$ and the $\mathrm{CO}_{2}$ activated $\mathrm{PNC}_{1 h}(\mathrm{c}, \mathrm{d}), \mathrm{PNC}_{2 \mathrm{~h}}(\mathrm{e}, \mathrm{f})$ and $\mathrm{PNC}_{3 \mathrm{~h}}(\mathrm{~g}, \mathrm{~h})$. 

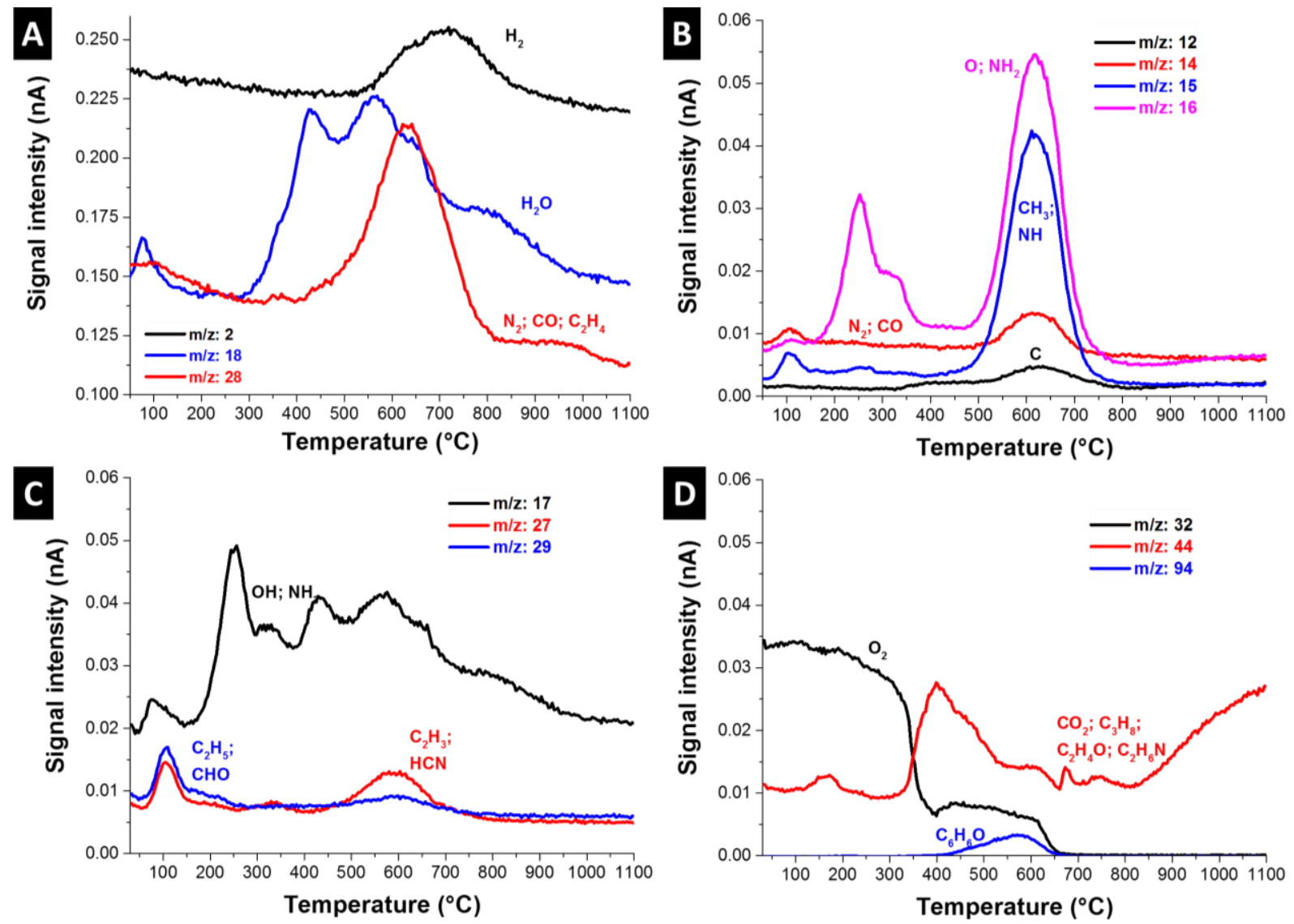

Figure S5: TGA-MS graphs (ionic current vs. temperature) of the pyrolysis of the polymeric beads for the $\mathrm{m} / \mathrm{z}: 2,18$, and $28(\mathrm{a}), \mathrm{m} / \mathrm{z}: 12,14,15$, and 16 (b), $\mathrm{m} / \mathrm{z}: 17,27$, and 29 (c), $\mathrm{m} / \mathrm{z}: 32,44$, and 94 (d). 

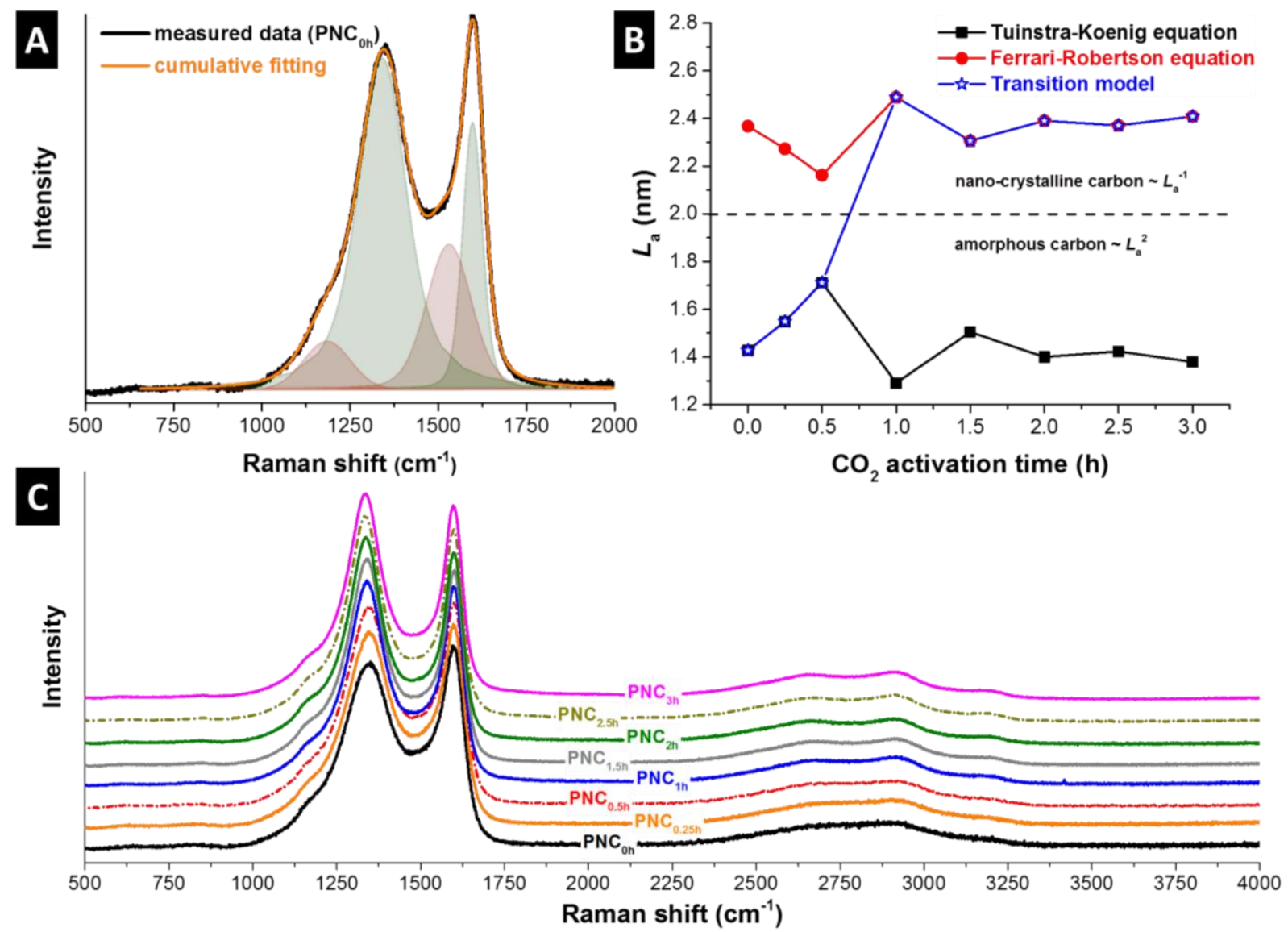

Figure S6: Raman spectra of $\mathrm{PN}_{\mathrm{oh}}$ showing the two-peak fitting for the D- and G-mode (A) and the average in-plane domain size $\left(L_{a}\right)$ calculated with the Tuinstra-Koenig (black) and Ferrari-Robertson equation (red) and assuming a transition between the two models regarding the $L_{a}$ values (blue) (B). Raman spectra of the pyrolyzed and activated carbon beads (C). The spectra were off-set by $10 \%$ along the $y$-axis for improved visibility. 


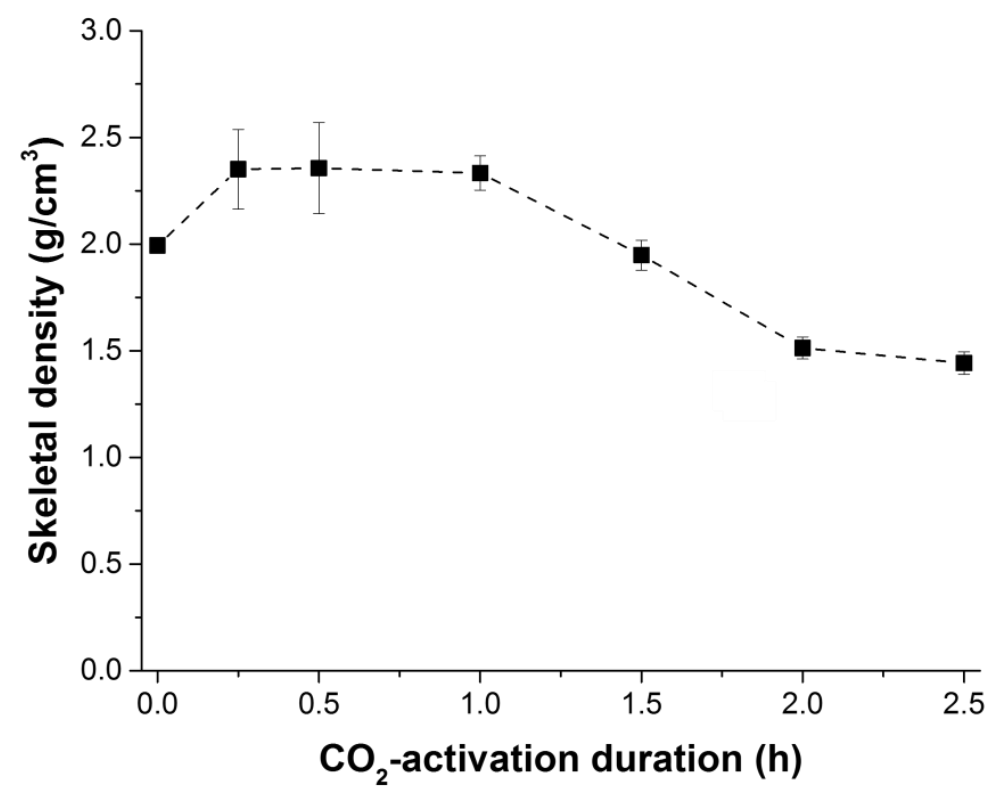

Figure S7: Skeletal density of the carbon beads vs. the $\mathrm{CO}_{2}$-activation duration measured by pyknometry. 

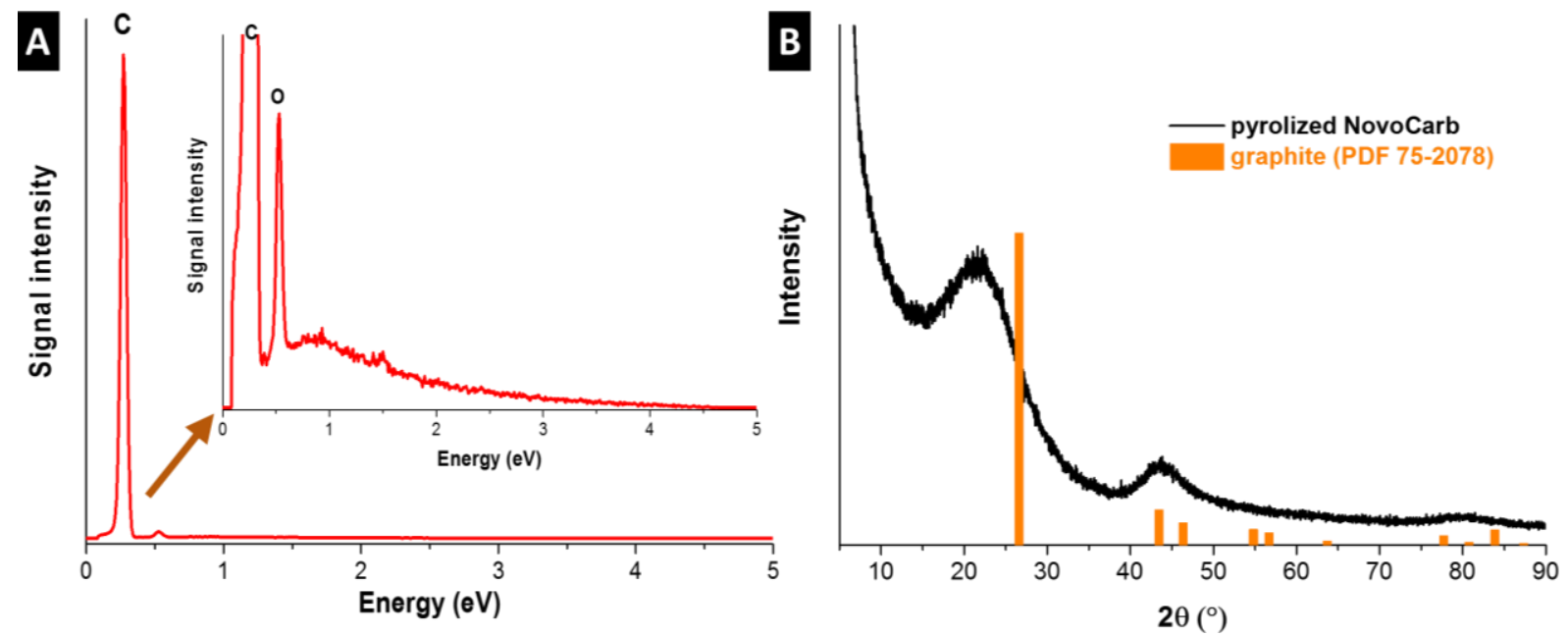

Figure S8: EDX spectra of the pyrolyzed carbon beads ( $P N_{o h}$ ) by an accelerating voltage of $5 \mathrm{keV}(\mathrm{A})$. Only carbon and oxygen can be clearly identified. XRD pattern of the pyrolized NovoCarb (at $1000{ }^{\circ} \mathrm{C}$ ), which is mainly amorphous (B). 

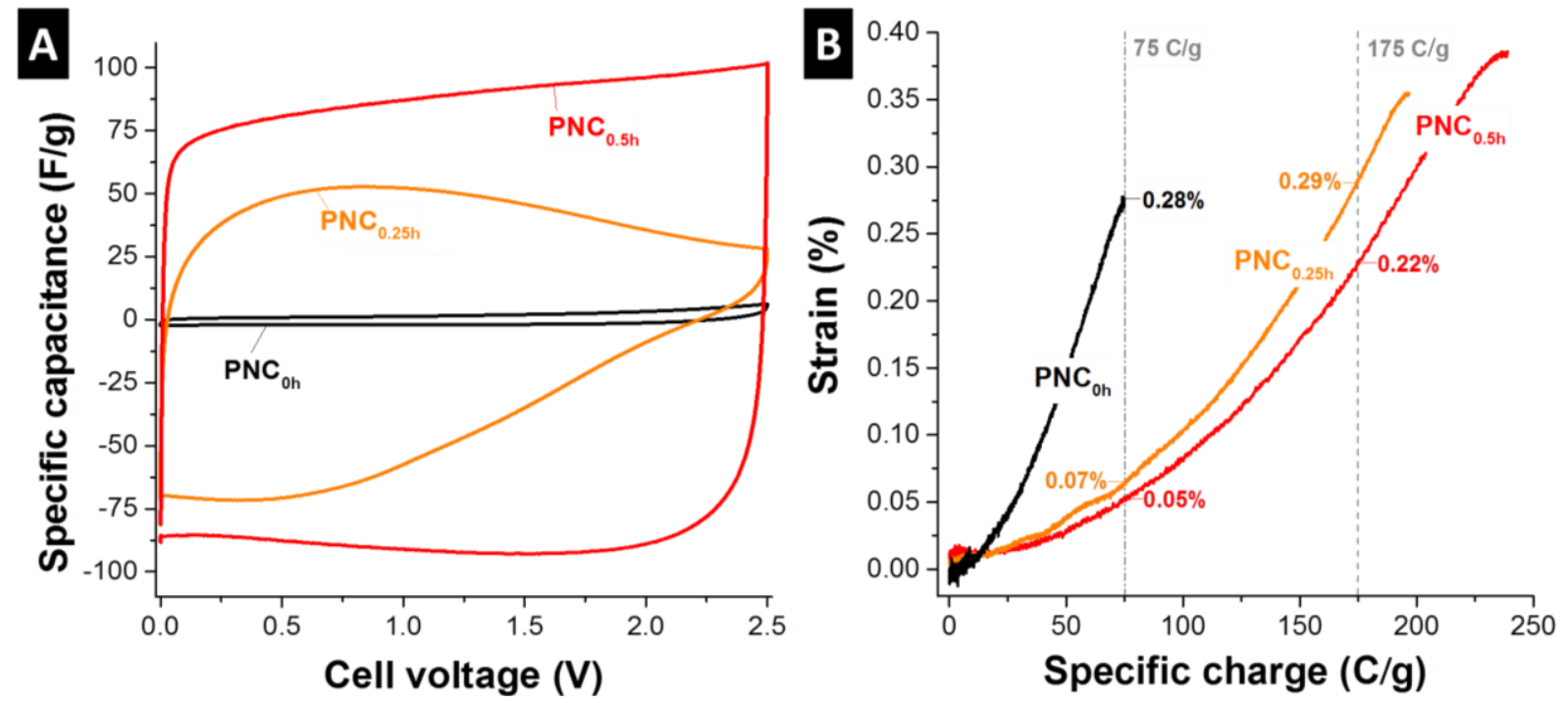

Figure 59: Cyclic voltammograms at $5 \mathrm{mV} / \mathrm{s}(\mathrm{A})$ and in-situ dilatometry data (B) of non-activated $\mathrm{PNC}_{\mathrm{oh}}$ and two activated novolac-derived carbons ( $\mathrm{PNC}_{0.25 \mathrm{~h}}$ and $\mathrm{PNC}_{0.5 \mathrm{~h}}$ ) in $1 \mathrm{M} \mathrm{TEA-BF} 4$ in $\mathrm{PC}$. The strain data were recorded with a scan rate of $1 \mathrm{mV} / \mathrm{s}$ and only data during charging (not discharging) are shown. For a relative comparison, the strain values at $75 \mathrm{C} / \mathrm{g}$ and $175 \mathrm{C} / \mathrm{g}$ are denoted. 

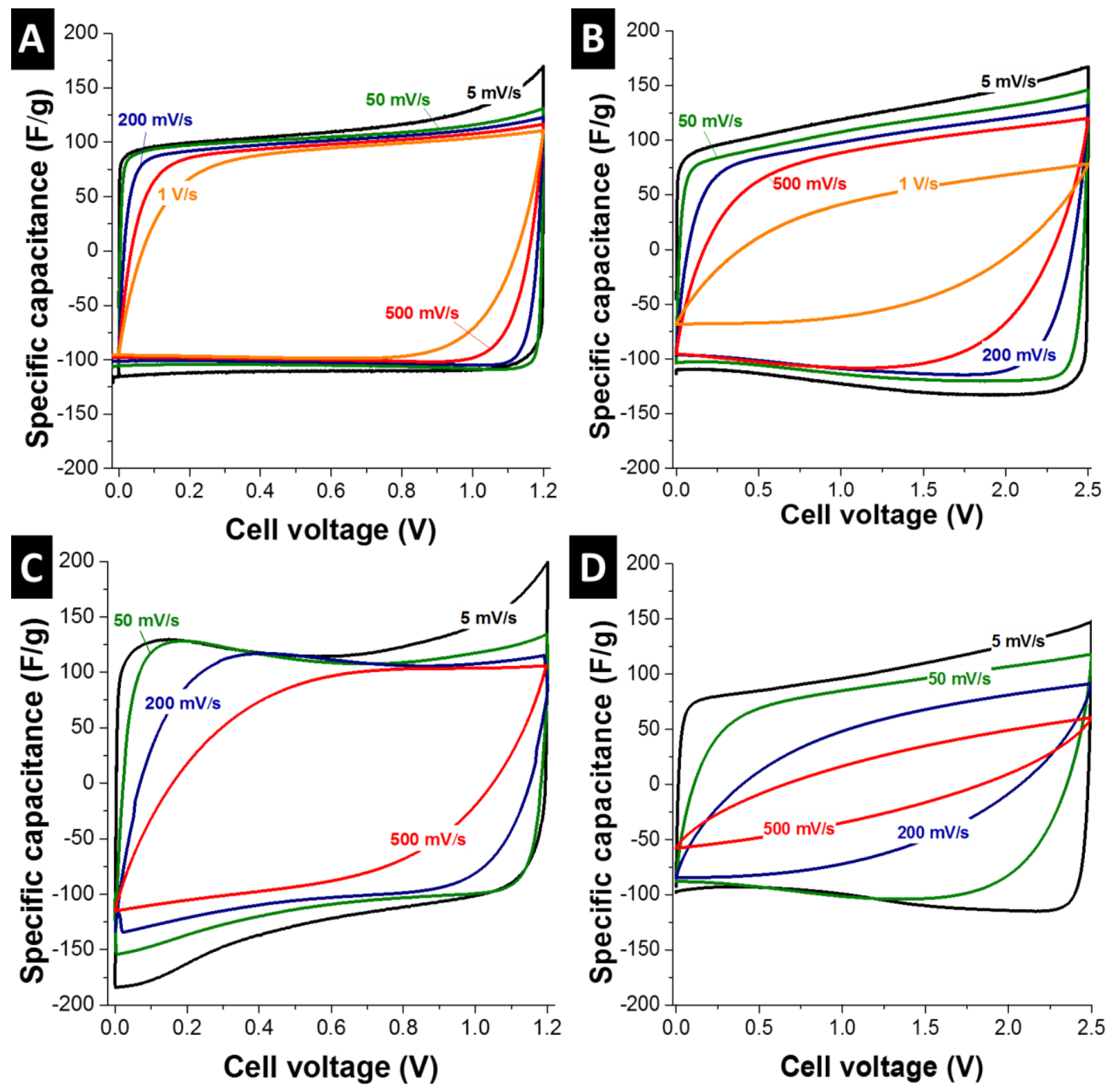

Figure S10: $\mathrm{CV}$ s of $\mathrm{PNC}_{2 \mathrm{~h}}$ in aqueous $1 \mathrm{M} \mathrm{Na}_{2} \mathrm{SO}_{4}(\mathrm{a})$ and in $1 \mathrm{M} \mathrm{TEA-BF} 4$ in $\mathrm{PC}$ (b) with a scan rate varying from $5 \mathrm{mV} / \mathrm{s}$ to $1 \mathrm{~V} / \mathrm{s}$ and $\mathrm{CV}$ s of $\mathrm{AC}$ in aqueous $1 \mathrm{M} \mathrm{Na}_{2} \mathrm{SO}_{4}$ (c) and in $1 \mathrm{M} \mathrm{TEA}-\mathrm{BF}{ }_{4}$ in PC (d) with a scan rate varying from $5 \mathrm{mV} / \mathrm{s}$ to $500 \mathrm{mV} / \mathrm{s}$. 